\title{
Mucinous cystic neoplasms of the mesentery: a case report and review of the literature
}

\author{
Georgios Metaxas*1, Athanasios Tangalos², Polyxeni Pappa ${ }^{2}$ and \\ Irene Papageorgiou ${ }^{3}$
}

Address: ${ }^{1}$ University Hospital of South Manchester, The Nightingale and Genesis Prevention Centre, Southmoor Road, M239LT, Manchester UK, ${ }^{2}$ Helena Venizelos General Hospital, 2nd Department of Surgery, GR-11521, Athens, Greece and ${ }^{3}$ Drama General Hospital, Department of Surgery, Drama, Greece

Email: Georgios Metaxas* - geometa@ hotmail.com; Athanasios Tangalos - vtangalos@hotmail.com; Polyxeni Pappa - papol@ath.forthnet.gr; Irene Papageorgiou - irene.pap@live.com

* Corresponding author

Published: 19 May 2009

World Journal of Surgical Oncology 2009, 7:47 doi:10.1 I86/1477-78/9-7-47

This article is available from: http://www.wjso.com/content/7/l/47

(c) 2009 Metaxas et al; licensee BioMed Central Ltd.

This is an Open Access article distributed under the terms of the Creative Commons Attribution License (http://creativecommons.org/licenses/by/2.0), which permits unrestricted use, distribution, and reproduction in any medium, provided the original work is properly cited.

\begin{abstract}
Background: Mucinous cystic neoplasms arise in the ovary and various extra-ovarian sites. While their pathogenesis remains conjectural, their similarities suggest a common pathway of development. There have been rare reports involving the mesentery as a primary tumour site.
\end{abstract}

Case presentation: A cystic mass of uncertain origin was demonstrated radiologically in a 22 year old female with chronic abdominal pain. At laparotomy, the mass was fixed within the colonic mesentery. Histology demonstrated a benign mucinous cystadenoma.

Methods and results: We review the literature on mucinous cystic neoplasms of the mesentery and report on the pathogenesis, biologic behavior, diagnosis and treatment of similar extra-ovarian tumors. We propose an updated classification of mesenteric cysts and cystic tumors.

Conclusion: Mucinous cystic neoplasms of the mesentery present almost exclusively in women and must be considered in the differential diagnosis of mesenteric tumors. Only full histological examination of a mucinous cystic neoplasm can exclude a borderline or malignant component. An updated classification of mesenteric cysts and cystic tumors is proposed.

\section{Background}

Cysts of the mesentery, retroperitoneum and omentum present with similar incidence in both sexes, varying between 1:260,000 and 1:27,000 in adults and 1:20,000 in children. They are usually incidental, or present with unspecific and chronic symptoms involving abdominal pain, distention, a palpable mass, gastrointestinal and urinary obstruction [1-3]. Acute manifestation is more often described in children and infants and may be associated with rupture [4-8], hemorrhage [9], torsion [10], infection or complicated hernia [11]. A 3\% malignancy rate has been demonstrated [1].

\section{Mucinous cystic neoplasms}

Mucinous cystic neoplasms (MCNs) arise in the ovary and various extra-ovarian sites, predominantly but not exclusively $[1,12-16]$ in adult females. The similarities between ovarian [17] and extra-ovarian MCNs suggest a common pathway of development. The cyst wall of extra-ovarian MCNs [18] is lined by mucin-secreting flat, cuboidal and/ 
or columnar epithelium associated with an underlying subepithelial ovarian like stroma (OLS). OLS is documented by histological features (spindle shaped cells and myofibroblastic proliferation on electron microscope study) and immunohistochemistry (positivity for vimentin, $\alpha$-smooth muscle actin and desmin) [19-22]. Although the presence of OLS is considered a requisite diagnostic criterion for MCNs, this is not always identified. MCNs have been extensively described in the pancreas [18-27], the appendix [28-30] and the hepatobiliary tract $[31,32]$ and more rarely in the retroperitoneum [3335] paratesticular tissues [36-41], lung [42-44]breast [45$47]$, spleen $[18,48,49]$ bowel [50] and the mesentery.

\section{Case presentation}

A 22 year old white-Caucasian female, with otherwise unremarkable history, presented with chronic, left sided, vague abdominal pain. There were no abnormal findings on clinical examination. Ultrasound (US), computerized tomography (CT) and magnetic resonance (MR) scans (Fig. 1a, b) demonstrated a unilocular cystic mass measuring $8.5 \times 6 \times 3.5 \mathrm{~cm}$ and lying medially to the descending colon. No definite preoperative diagnosis could be established. At laparotomy the mass was fixed within the descending and sigmoid colonic mesentery (Fig. 2). As there were no firm adhesions or shared blood supply (Fig. 3 ), enucleation was easily performed. The cyst had a macroscopically thin and smooth wall and contained whiteyellowish fluid. The cyst wall was examined in its entirety. Histology demonstrated two distinct components: an outer ovarian-like stromal layer, composed of densely packed spindle-shaped cells (Fig. 4) and an inner epithelial layer, consisting of cuboidal and columnar mucinous cells (Fig. 5, 6). Immunohistochemical study of the stromal cells demonstrated positivity for vimentin, actin, and desmin. The epithelial cells showed positivity for cytokeratin-7 (Fig. 6), CA-125 (Fig. 7), CEA, and CA 19-9 and negative expression of cytokeratin-20. There was no cellular atypia. The overall features suggested a benign neoplasm of epithelial origin with the appearance of an ovarian mucinous cystadenoma. The patient recovered uneventfully and remained well on annual follow-up with abdominal US.

\section{Discussion}

There are thirteen documented cases of mesenteric MCNs in the literature prior to this report (Table 1). Five of those originated from the mesentery of the small intestine $[15,18,51-53]$, one from the mesoappendix [54] and seven from the mesocolon [55-60]. The only male patient was a five year old child with an unresectable neoplasm [15]. Clinical presentation typically involved chronic abdominal pain $(n=8)$ and distention $(n=5)$. Three patients were asymptomatic and one presented with acute manifestation of symptoms. Interestingly, preoperative imaging was inconclusive in nine cases, suggested ovarian origin in four cases, and mesenteric origin in only one case. No pathognomonic malignant features were illustrated. Pathology reported nine benign mucinous cystadenomas (including the present case), three borderline MCNs, (based on the presence of atypical nuclei, pseudostratification, glandular arrangements and lack of invasion) and two carcinomas. The median age at diagnosis of benign mesenteric MCNs was 26.1 yrs, compared to 35.2 yrs for non-benign tumours. One of the carcinomas [51] was thought to be the result of malignant transformation following earlier incomplete excisions of a recurrent benign tumour. One of the patients with a borderline tumour, presented with metastatic disease in the mediastinal lymph nodes four years after removal, which may

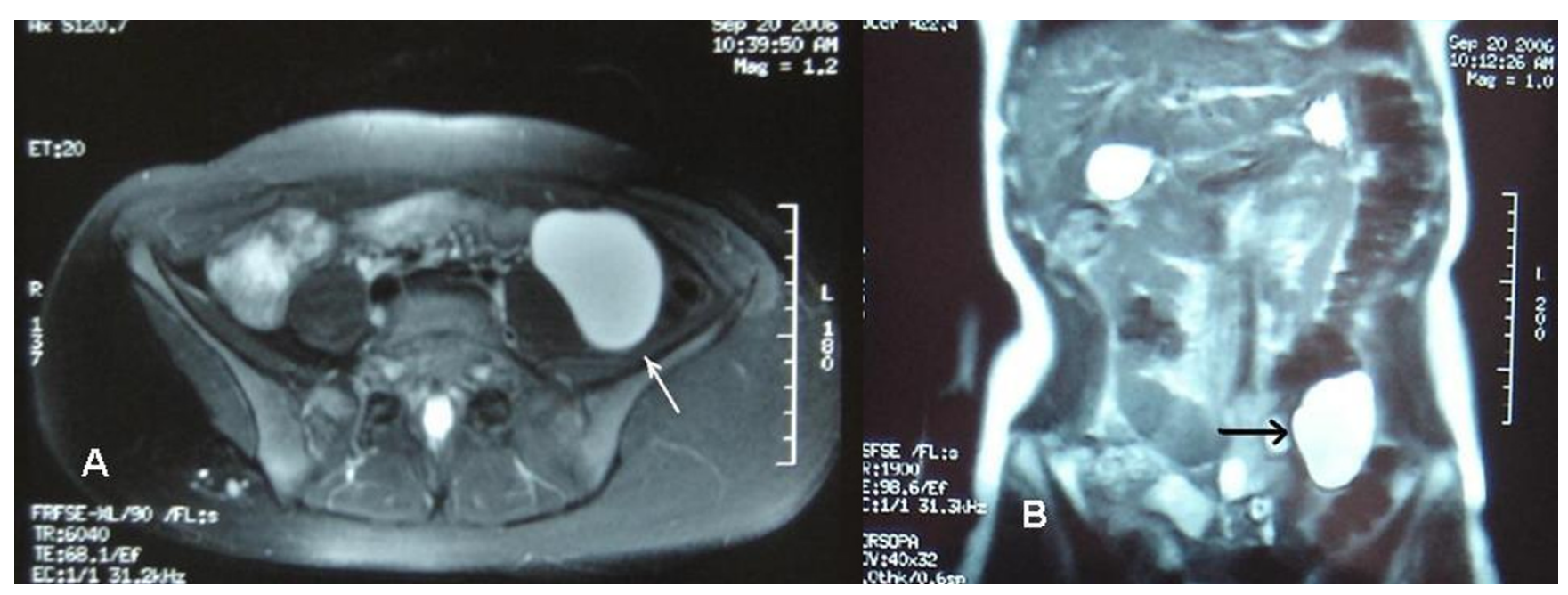

Figure I

(a, b): MR scan appearance of the cystic tumour (arrow). 


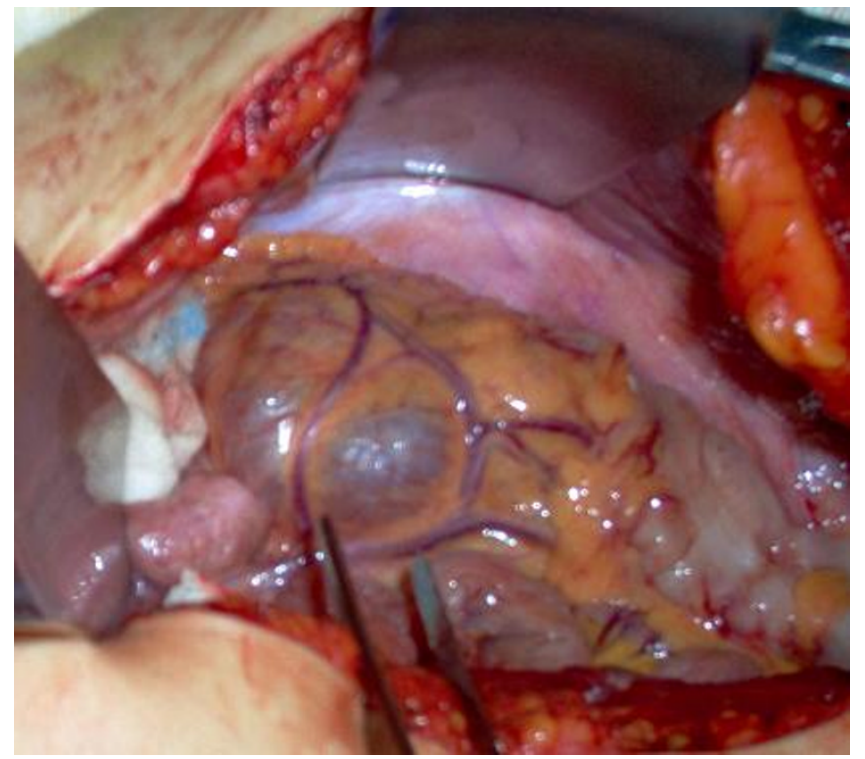

Figure 2

Intra-operative appearance, medial view of the mesentery, inferion mesenteric vessels lying on the cyst surface.

represent a missed invasive focus due to incomplete examination of the entire neoplasm wall. This patient had initially undergone a partial colectomy and salpingooophoretomy [55]. Another two patients underwent partial colectomies due to cyst wall adhesions, while enucleation of the tumor was performed in six. Partial cystectomy was performed in two unresectable tumors. Immunohistochemistry was reported in four cases. There

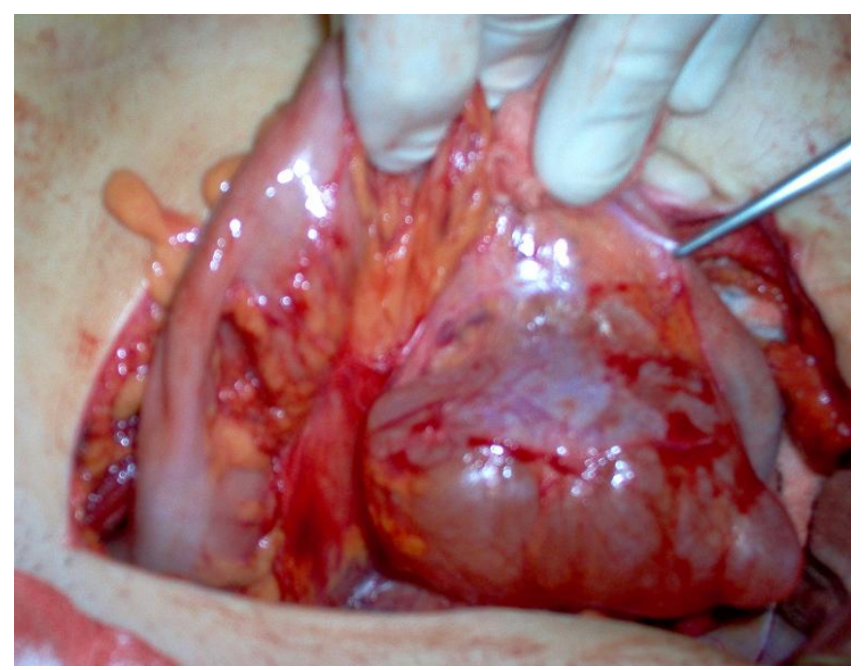

\section{Figure 3}

Lateral view of mesentery, cyst enucleation in an avascular plane.

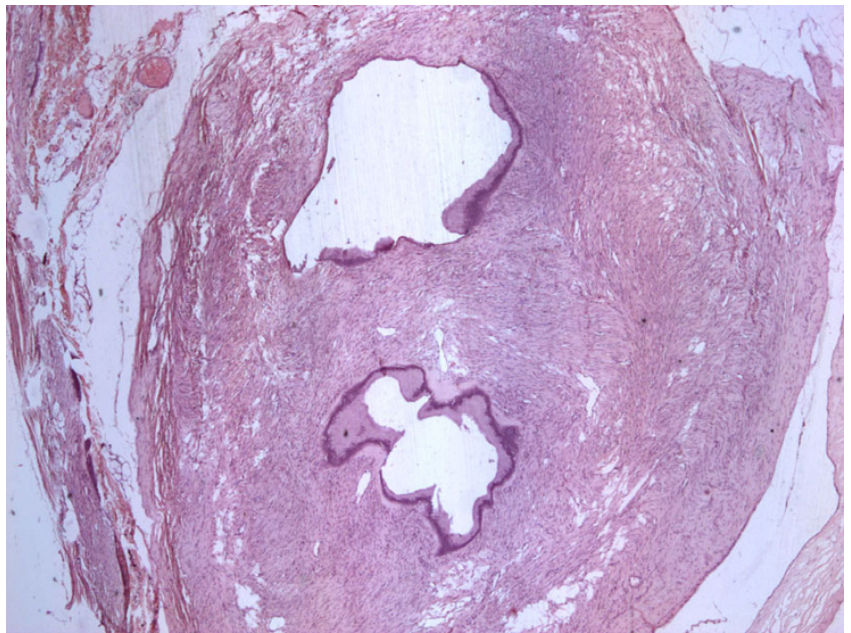

Figure 4

Microscopic appearance of the cyst wall, ovarian like stroma, epithelial lining.

was no report of ectopic ovarian tissue or evidence of teratomatous developement. There was no association between the age and tumor size.

\section{Pathogenesis and biologic behavior of extra-ovarian MCNs}

The origin of extra-ovarian MCNs has been sporadically attributed to implanted or ectopic ovarian tissue [61], supernumerary ovaries $[62,63]$ or mono-phyletic developement of a teratoma component [64-66]. A recent concept linked the development of hepatic and pancreatic MCNs to the migration of epithelial cells from the embry-

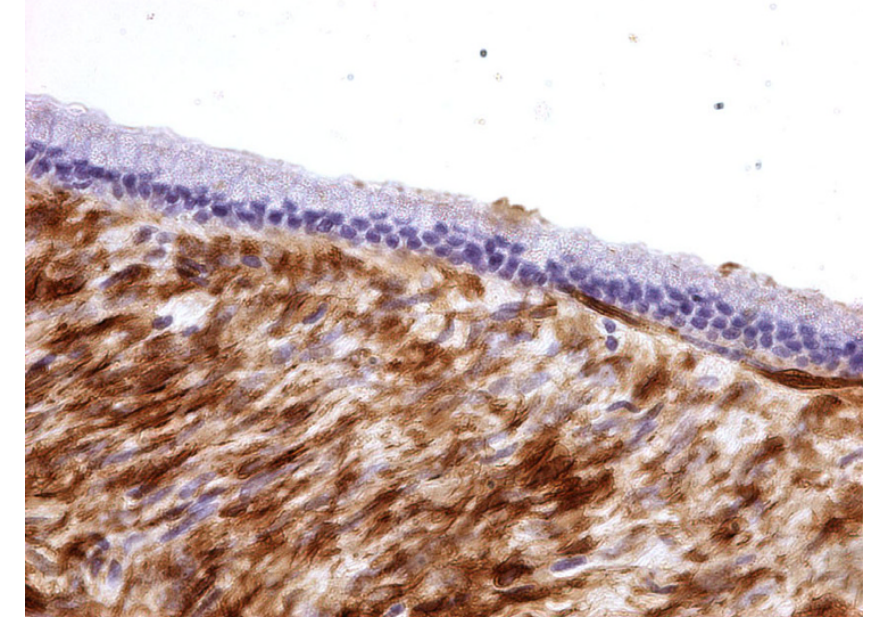

Figure 5

Benign columnar mucinous epithelium lining of the cyst wall. Immunohistochemistry reveals stromal positivity for actin. 


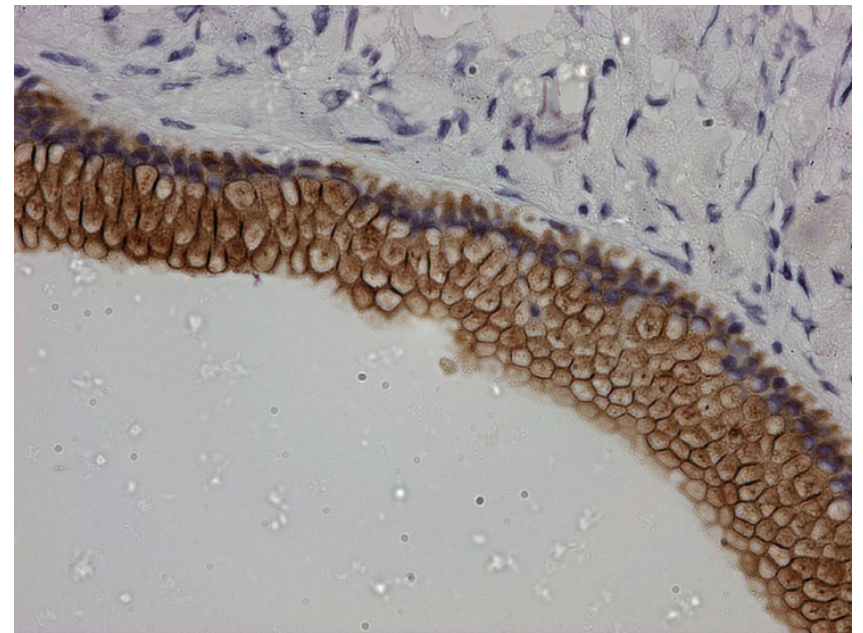

Figure 6

Immunohistochemistry, epithelial positivity for CK 7.

onic gonads during early foetal life [67]. The most widely accepted theories for the pathogenesis of extra-ovarian MCNs include: Coelomic metaplasia of epithelial cells or invaginated peritoneum along the course of ovarian descent, mucinous metaplasia in pre-existing mesothelial cysts and neoplastic differentiation of epithelial cells from a secondary extragenital Mullerian system [1,2,51,68-71].

According to the WHO classification (ICD 10), MCNs are divided into benign adenomas, borderline tumours, noninvasive (in situ) and invasive carcinomas. The malignant potential of all MCNs is supported by observations of malignant transformation of benign neoplasms during

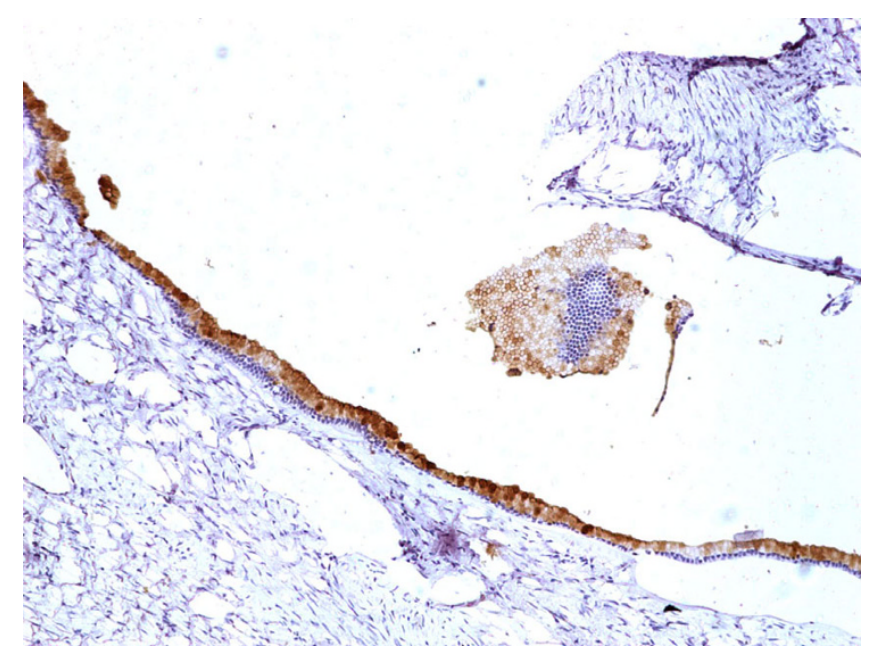

\section{Figure 7}

Immunohistochemistry, epithelial positivity for CA125. long term follow up [24,51]. Other authors noticed a frequent concurrence of benign and focally borderline or/ and malignant epithelium $[21,72,73]$. Also, as illustrated in the present study and previous pancreatic MCNs series $[72,74]$, the median age at diagnosis is higher for malignant MCNs, which implies progression from adenoma to carcinoma. Consequently, failure to excise or study the entire cyst wall may result in the miscategorization of a neoplasm [75].

When differentiating mucinous from non mucinous neoplasms and non neoplastic cysts and evaluating their malignant potential, the following features may have a positive predictive but not pathognomonic value: Patient age and tumour size $[27,74]$, multilocularity, presence of calcifications [58], intracystic papillary projections or mural nodules [20], presence or lack of OLS [20,76], nuclei atypia, co-expression of (a6)-integrin and p53 immunoactivity $[20,77]$, high viscosity and/or high levels of CEA in the cyst fluid and positivity of other tumours markers (Ca 19-9, Ca-125, Ca 15-3) [24,78,79]. Oestrogen and progesterone receptor positivity in stromal cells varies [80].

\section{Classification of mesenteric cysts and cystic tumors}

None of the recognized classifications of mesenteric cysts [81-85], has included MCNs up to date. Malignant mesothelioma is suggested as the only potential primary cystic malignancy in the mesentery. We found three more cases of primary mesenteric cystic neoplasms in the literature [86-88], as well as reports of mesenteric hydatid [8,8992]] and tuberculous cysts [93-95]. In view of the existing data, we propose an updated classification of mesenteric cysts and cystic tumors, as shown in the Appendix.

\section{Diagnosis and treatment}

There is no definitive diagnostic test. Radiological examinations may suggest the origin of a cyst, but cannot exclude the malignant potential of an MCN [35,82,84,9699]. Guided aspiration cytology and fluid analysis is rarely diagnostic, has a high false negative incidence [100] and may only be helpful in the complicated management of pancreatic cystic masses [101,102]. The definite diagnosis remains postoperative and therefore intra-operative frozen section does not have any use. Following exclusion of non-surgical conditions, complete excision is the only treatment option for all mesenteric neoplasms [103-105] because of their malignant potential as well as the high recurrence rate of benign tumors - such as lymphangiomas and mesotheliomas - after incomplete resection [106-108]. Open or laparoscopic approach depends on the surgeon's skills, as more complicated resections may be required [109-111]. Only one mesenteric MCN has been treated laparoscopically up to date, by a gynaecologist [54]. 
Table I: Reported cases of mesenteric mucinous cystic neoplasms of the large intestine (I-8), small intestine (9-I3) and appendix (I4). *No details contained in published article.

\begin{tabular}{|c|c|c|c|c|c|c|c|c|}
\hline s & Reference & Age Sex & $\begin{array}{l}\text { Clinical } \\
\text { presentation }\end{array}$ & $\begin{array}{l}\text { Imaging tests - } \\
\text { correlated } \\
\text { diagnosis }\end{array}$ & Size $(\mathrm{cm})$ & Site & Operation & $\begin{array}{l}\text { Histology - } \\
\text { Immunohistochemistry }\end{array}$ \\
\hline I. & $\begin{array}{l}\text { Banerjee et al. } \\
(1988)[55]\end{array}$ & $58 \mathrm{~F}$ & Incidental finding & US, Uncertain & 7 & Hepatic flexure & $\begin{array}{l}\text { Right } \\
\text { Hemicoletomy }\end{array}$ & $\begin{array}{l}\text { Benign mucinous } \\
\text { cystadenoma }\end{array}$ \\
\hline 2. & & $38 \mathrm{~F}$ & Pain, distention & US, Uncertain & II & $\begin{array}{l}\text { Descending } \\
\text { colon }\end{array}$ & $\begin{array}{l}\text { Colectomy } \\
\text { Salpingo- } \\
\text { oophorectomy }\end{array}$ & $\begin{array}{l}\text { Borderline malignant } \\
\text { MCN }\end{array}$ \\
\hline 3. & $\begin{array}{l}\text { McEvoy et al. } \\
\text { (1997) [56] }\end{array}$ & $24 \mathrm{~F}$ & $\begin{array}{l}\text { Pain, constipation } \\
\text { distension. }\end{array}$ & $\begin{array}{l}\text { US, Ovarian } \\
\text { origin }\end{array}$ & $20 \times 15$ & Sigmoid colon. & Enucleation & $\begin{array}{l}\text { Benign mucinous } \\
\text { cystadenoma (CAM 5.2, } \\
\text { CEA)+, Factor VIII - }\end{array}$ \\
\hline 4. & $\begin{array}{l}\text { Linden et al. } \\
(2000)[58]\end{array}$ & $32 \mathrm{~F}$ & Incidental finding & $\begin{array}{l}\text { US, CT, } \\
\text { Uncertain }\end{array}$ & $13 \times 10 \times 10$ & $\begin{array}{l}\text { Transverse } \\
\text { colon }\end{array}$ & Enuleation & $\begin{array}{l}\text { Mucinous } \\
\text { cystadenocarcinoma }\end{array}$ \\
\hline 5. & $\begin{array}{l}\text { Vrettos et al. } \\
(2000) \text { [59] }\end{array}$ & $38 \mathrm{~F}$ & $\begin{array}{l}\text { Pain, nausea, } \\
\text { vomiting, } \\
\text { distention, oedema } \\
\text { of the lower limbs }\end{array}$ & $\begin{array}{l}\text { US, CT } \\
\text { Mesenteric cyst }\end{array}$ & $17 \times 12$ & Sigmoid colon. & Enucleation & $\begin{array}{l}\text { Borderline malignant } \\
\text { MCN }\end{array}$ \\
\hline 6. & $\begin{array}{l}\text { Talwar et al. } \\
\text { (2004) [57] }\end{array}$ & $32 \mathrm{~F}$ & $\begin{array}{l}\text { Acute pain, } \\
\text { vomiting, urinary } \\
\text { frequency, } \\
\text { constipation }\end{array}$ & $\begin{array}{l}\text { US, Ovarian } \\
\text { origin }\end{array}$ & $10 \times 7 \times 5$ & $\begin{array}{l}\text { Descending } \\
\text { colon }\end{array}$ & $\begin{array}{l}\text { Left } \\
\text { hemicolectomy }\end{array}$ & $\begin{array}{l}\text { Borderline malignant } \\
\text { MCN }\end{array}$ \\
\hline 7. & $\begin{array}{l}\text { Swaveling et al. } \\
(2008)[60]\end{array}$ & $18 \mathrm{~F}$ & $\begin{array}{l}\text { Asymptomatic } \\
\text { abdominal swelling }\end{array}$ & $\begin{array}{l}\text { US, CT, } \\
\text { Uncertain } \\
\text { Adjacent to R } \\
\text { kidney }\end{array}$ & 15 & Right hemicolon & Enucleation & $\begin{array}{l}\text { Benign mucinous } \\
\text { cystadenoma }\end{array}$ \\
\hline 8. & Present case & $22 \mathrm{~F}$ & Pain & $\begin{array}{l}\text { US, CT, MRI, } \\
\text { Uncertain }\end{array}$ & $8.5 \times 6 \times 3.5$ & $\begin{array}{l}\text { Descending + } \\
\text { sigmoid colon }\end{array}$ & Enucleation & $\begin{array}{l}\text { Benign mucinous } \\
\text { cystadenoma (CK7, } \\
\text { CEA, CA I9-9, CAI } 25 \text {, } \\
\text { actin, desmin, } \\
\text { vimentin)+, ck20(-), }\end{array}$ \\
\hline 9. & $\begin{array}{l}\text { Cohen et al } \\
(1988)[52]\end{array}$ & $36 \mathrm{~F}$ & $\begin{array}{l}\text { Found during } \\
\text { pregncy }\end{array}$ & Uncertain & 40 & Ileum & Cyst resection & $\begin{array}{l}\text { Benign mucinous } \\
\text { cystadenoma }\end{array}$ \\
\hline 10. & $\begin{array}{l}\text { Bury and Pricolo } \\
\text { (1994) [5I] }\end{array}$ & $36 \mathrm{~F}$ & $\begin{array}{l}\text { Pain, reccurent } \\
\text { unresectable cysts } \\
\text { én a } 13 \text { year } \\
\text { period, }\end{array}$ & CT & $*$ & $\begin{array}{l}\text { Small intestine } \\
\text { Unspecified }\end{array}$ & $\begin{array}{l}\text { Partial cyst } \\
\text { resections }\end{array}$ & $\begin{array}{l}\text { Incomplete excision, } \\
\text { transformation to } \\
\text { carcinoma CK+, EMA, } \\
\text { CEA, B72.3, Leu MI }\end{array}$ \\
\hline II. & $\begin{array}{l}\text { Czubalski et al. } \\
(2004)[53]\end{array}$ & $38 \mathrm{~F}$ & $\mathrm{~N} / \mathrm{A}$ & Ovarian origin & $\mathrm{N} / \mathrm{A}$ & $\mathrm{N} / \mathrm{A}$ & N/A & $\begin{array}{l}\text { Benign mucinous } \\
\text { cystadenoma }\end{array}$ \\
\hline 12. & $\begin{array}{l}\text { Shioho et al } \\
(2006)[18]\end{array}$ & $14 \mathrm{~F}$ & $*$ & $*$ & 15 & $*$ & $*$ & $\begin{array}{l}\text { Benign mucinous } \\
\text { cystadenoma }\end{array}$ \\
\hline 13. & $\begin{array}{l}\text { Luo et al (2008) } \\
{[15]}\end{array}$ & $5 M$ & $\begin{array}{l}\text { Abdominal pain } \\
\text { and swelling }\end{array}$ & None & $20-25$ & $\begin{array}{l}\text { Small intestine } \\
\text { Unspecified }\end{array}$ & $\begin{array}{l}\text { Unresectable, } \\
\text { Segmental } \\
\text { excision }\end{array}$ & $\begin{array}{l}\text { Benign mucinous } \\
\text { cystadenoma, (biopsy } \\
\text { only) ER, PR (-), Inhibin } \\
(+), \text { OLS + }\end{array}$ \\
\hline 14. & $\begin{array}{l}\text { Felemban \& } \\
\text { Tulandi }(2000) \\
{[54]}\end{array}$ & $20 \mathrm{~F}$ & $\begin{array}{l}\text { Abdominal pain, } \\
\text { back ache }\end{array}$ & $\begin{array}{l}\text { US, Ovarian } \\
\text { origin }\end{array}$ & $7.6 \times 7 \times 5.3$ & Appendix & $\begin{array}{l}\text { Lap. Enucleation, } \\
\text { appendicectomy }\end{array}$ & $\begin{array}{l}\text { Benign mucinous } \\
\text { cystadenoma }\end{array}$ \\
\hline
\end{tabular}

\section{Conclusion}

Mucinous cystic neoplasms of the mesentery present almost exclusively in women and must be considered in the differential diagnosis of mesenteric tumors. Whilst there are no pathognomonic diagnostic criteria, a mesenteric cyst should be approached as potentially malignant especially in adults. Only complete excision and full histological examination of a mucinous cystic neoplasm can exclude a borderline or malignant component. We propose an updated classification of mesenteric cysts.

\section{Consent}

Written informed consent was obtained from the patient for publication of this case report and any accompanying images. A copy of the written consent is available for review by the Editor-in-Chief of this journal

\section{Competing interests}

The authors declare that they have no competing interests. 


\section{Authors' contributions}

GM and AT were involved in the treatment of the patient, study design and drafting of the manuscript. GM also reviewed literature, prepared the tables and figures and edited the final version. PP and IP collected case details and helped in the literature search and drafting of the manuscript. All authors read and approved the final manuscript.

\section{Appendix \\ Proposed updated classification of mesenteric cysts and cystic tumors}

Mesenteric Cysts and Cystic Tumors

Cysts of lymphatic origin

- Simple lymphatic cyst

- Lymphangioma

Cysts of mesothelial origin

- Simple mesothelial cyst

- Benign cystic mesothelioma

- Malignant cystic mesothelioma

Cysts of enteric origin

- Enteric duplication cyst

- Enteric cyst

Mucinous cystic neoplasms

- Mucinous cystadenoma

- Borderline malignant mucinous cystic neoplasm

- Mucinous cystadenocarcinoma

Cysts of urogenital origin

Miscellaneous neoplasms

- Mature cystic teratoma

- Neuroendocrine carcinoma

- Cystic spindle cell tumor

Non - neoplastic cysts

- Hydatid cyst
- Tuberculous cyst

Non - pancreatic pseudocysts

- Haematoma

- Abscess

\section{Acknowledgements}

Authors wish to thank Ms Cliona Kirwan, Lecturer in Surgical Oncology at the University of Manchester, for her assistance in editing the article.

\section{References}

I. Kurtz R, Heimann T, Beck R, et al.: Mesenteric and retroperitoneal cysts. Ann Surg 1986:109-1/2.

2. Vanek VW, Phillips AK: Retroperitoneal, mesenteric and omental cysts. Arch Surg 1984, I I 9:838-42.

3. Liew SC, Glenn DC, Storey DW: Mesenteric cyst. ANZJ Surg 1994, 64:74I-744.

4. Pisano G, Erdas E, Parodo G, et al.: Acute abdomen due to rupture of mesenteric cysts. Observations on a clinical case and review of the literature. Minerva Chir. 2004, 59(4):405-4II.

5. Ekçi B, Ayan F, Gürses B: Ruptured mesenteric cyst: a rare presentation after trauma. Ulus Travma Acil Cerrahi Derg 2007, 13(I):74-7.

6. Vlazakis SS, Gardikis S, Sanidas E, et al.: Rupture of mesenteric cyst after blunt abdominal trauma. Eur J Surg 2000, 166(3):262-4.

7. Takeuchi K, Takaya Y, Maeda K, et al:: Peritonitis caused by a ruptured, infected mesenteric cyst initially interpreted as an ovarian cyst. A case report. J Reprod Med 2004, 49(I):65-7.

8. Kusaslan R, Sahin DA, Belli AK, et al.: Rupture of a mesenteric hydatid cyst: a rare cause of acute abdomen. Can J Surg 2007, 50(5): $\mathrm{E} 3-4$

9. Okamoto D, Ishigami K, Yoshimitsu K, et al.: Hemorrhagic mesenteric cystic lymphangioma presenting withacute lower abdominal pain: the diagnostic clues on MR Imaging. Emerg Radiol 2008.

10. Addison NV: Torsion of a mesenteric lymphatic cyst. Br Med J 1953, I(4823): 1316

II. Polat C, Tokyol C, Dilek ON: Strangulated umbilical hernia including a mesenteric cyst: a rare cause of acute abdomen. Acta Chir Belg 2003, 103(3):329-31.

12. Green JM, Bruner BC, Tang WW, et al:: Retroperitoneal mucinous cystadenocarcinoma in a man: case report and review of the literature. Urol Oncol 2007, 25(I):53-5.

13. Thamboo TP, Sim R, Tan SY, et al.: Primary retroperitoneal mucinous cystadenocarcinoma in a male patient. Clin Pathol 2006, 59(6):655-7.

14. Saw EC, Ramachandra S: Laparoscopic resection of a giant mesenteric cyst. Surg Laparosc Endosc 1994, 4(I):59-6I.

15. Luo JJ, Baksh FK, Pfeifer JD, et al.: Abdominal mucinous cystic neoplasm in a a male child. Pediatr Dev Pathol 2008, I I(I):46-9.

16. Prabhuraj AR, Basu A, Sistla SC, et al.: Primary retroperitoneal mucinous cystadenoma in a man. Am J Clin Oncol 2008, $3 I(5): 519-20$.

17. Hart WR: Mucinous tumors of the ovary: a review. Int J Gynecol Pathol 2005, 24(I):4-25.

18. Shiono S, Suda K, Nobukawa B, et al.: Pancreatic, hepatic, splenic, and mesenteric mucinous cystic neoplasms (MCN) are lumped together as extraovarian MCN. Pathology International 2006, 56:7|-77.

19. Izumo A, Yamaguchi K, Eguchi T, et al.: Mucinous cystic tumor of the pancreas: immunohistochemical assessment of "ovarian type stroma.". Oncol Rep 2003, 10:515-525.

20. Zamboni G, Scarpa A, Bogina G, et al:: Mucinous cystic tumors of the pancreas: clinicopathological features, prognosis, and relationship to other mucinous cystic tumors. Am J Surg Pathol 1999, 23:410-422.

21. Thompson LD, Becker RC, Przygodzki RM, et al.: Mucinous cystic neoplasm (mucinous cystadenocarcinoma of low grade 
malignant potential) of the pancreas: a clinicopathologic study of 130 cases. Am J Surg Pathol 1999, 23:1-16.

22. Fukushima N, Mukai K: 'Ovarian-type' stroma of pancreatic mucinous cystic tumor expresses smooth muscle phenotype. Pathol Int 1997, 47:806-808.

23. Adsay NV: Cystic neoplasia of the pancreas: pathology and biology. J Gastrointest Surg 2008, I 2(3):40I-4.

24. Kloppel G, Solcia E, Longnecker DS, et al:: Histological typing of tumors of the exocrine pancreas. 2nd edition. Berlin: Springer; 1996.

25. Le Borgne J, De Calan L, Partensky C: Cystadenomas and Cystadenocarcinomas of the Pancreas. A Multiinstitutional Retrospective Study of 398 Cases. Ann Surg 1999, 230(2): I52-61.

26. Goh BK, Tan YM, Chung YF, et al.: A review of mucinous cystic neoplasms of the pancreas defined by ovarian-type stroma: clinicopathological features of $\mathbf{3 4 4}$ patients. World J Surg 2006, 30( I 2):2236-45.

27. Reddy RP, Smyrk TC, Zapiach M, et al.: Pancreatic mucinous cystic neoplasm defined by ovarian stroma: demographics, clinical features, and prevalence of cancer. Clin Gastroenterol Hepatol 2004, 2(I I): 1026-3I.

28. Smeenk RM, Van Velthuysen MLF, Verwaal VJ, et al:: Appendiceal neoplasms and pseudomyxoma peritonei: $A$ population based study. Eur J Surg Oncol. 2008, 34(2): |96-20|

29. Ruiz-Tovar J, Garcýa Teruel D, Morales Castineiras V, et al: Mucocele of the Appendix. World / Surg 2007, 3 I:542-548.

30. Karakaya K, Barut F, Emre AU, et al: Appendiceal mucocele: case reports and review of current literature. World J Gastroenterol 2008, I 4(4):2280-3.

31. Devaney K, Goodman ZD, Ishak KG: Hepatobiliary cystadenoma and cystadenocarcinoma. A light microscopic and immunohistochemical study of $\mathbf{7 0}$ patients. Am J Surg Pathol 1994, I8(II):|078-9|.

32. Vogt DP, Henderson JM, Chmielewski E: Cystadenoma and cystadenocarcinoma of the liver: a single center experience. J Am Coll Surg 2005, 200(5):727-33.

33. Bifulco G, Mandato VD, Giampaolino $P$, et al.: Huge primary retroperitoneal mucinous cystadenoma of borderline malignancy mimicking an ovarian mass: case report and review. Anticancer Res 2008, 28(4C):2309-I5.

34. Yan SL, Lin H, Kuo CL, et al.: Primary retroperitoneal mucinous cystadenoma: Report of a case and review of the literature. World J Gastroenterol 2008, I 4(37):5769-72.

35. Yang DM, Jung DH, Kim H, et al.: Retroperitoneal cystic masses: CT, clinical, and pathologic findings and literature review. Radiographics 2004, 24(5): I353-65.

36. Ulbright TM, Young RH: Primary mucinous tumors of the testis and paratestis: a report of nine cases. Am J Surg Pathol 2003 27(9): $|22|-8$

37. Uschuplich V, Hilsenbeck JR, Velasco CR: Paratesticular mucinous cystadenoma arising from an oviduct-like müllerian remnant: a case report and review of the literature. Arch Pathol Lab Med 2006, I30(I I): I7I5-7.

38. Rizzardi C, Brollo A, Thomann B, et al.: Intra-abdominal ovariantype mucinous cystadenoma associated with fallopian tubelike structure and aberrant epididymal tissue in a male patient. Hum Pathol 2005, 36(8):927-3I.

39. Shimbo M, Araki K, Kaibuchi T, et al.: Mucinous cystadenoma of the testis. J Urol 2004, I 72(I): I 46-7.

40. Naito S, Yamazumi K, Yakata Y, et al.: Immunohistochemical examination of mucinous cystadenoma of the testis. Pathol lnt 2004, 54(5):355-9.

4I. Nokubi M, Kawai T, Mitsu S, et al.: Mucinous cystadenoma of the testis. Pathol Int 2002, 52(10):648-52.

42. Ishibashi H, Moriya T, Matsuda Y, et al.: Pulmonary mucinous cystadenocarcinoma: report of a case and review of the literature. Ann Thorac Surg 2003, 76(5): 1738-40.

43. Gao ZH, Urbanski Sj: The spectrum of pulmonary mucinous cystic neoplasia: a clinicopathologic and immunohistochemical study of ten cases and review of literature. Am J Clin Pathol 2005, I 24(I):62-70

44. Wynveen C, Behmaram B, Haasler G, et al: Diverse histologic appearances in pulmonary mucinous cystic neoplasia: A case report. J Med Case Reports. 2008, 29(2):312.

45. Koenig C, Tavassoli FA: Mucinous cystadenocarcinoma of the breast. Am J Surg Pathol 1998, 22(6):698-703.
46. Chen WY, Chen CS, Chen HC, et al.: Mucinous cystadenocarcinoma of the breast coexisting with infiltrating ductal carcinoma. Pathol Int 2004, 54(10):78I-6.

47. Lee $\mathrm{SH}$, Chaung CR: Mucinous metaplasia of breast carcinoma with macrocystic transformation resembling ovarian mucinous cystadenocarcinoma in a case of synchronous bilateral infiltrating ductal carcinoma. Pathol Int 2008, 58(9):60 I-5.

48. Morinaga S, Ohyama R, Koizumi J: Low-grade mucinous cystadenocarcinoma in the spleen. Am / Surg Pathol 1992, 16(9):903-8.

49. Hirota $M$, Hayashi N, Tomioka T, et al.: Mucinous cystadenocarcinoma of the spleen presenting a point mutation of the Kirsten-ras oncogene at codon 12. Dig Dis Sci 1999, 44(4):768-74.

50. Shaco-Levy R, Tsodikov V, Levy I: Mucinous cystadenoma of the ascending colon: a novel presentation. Scand J Gastroenterol 2003, 38(II): II 193-5.

5I. Bury TF, Pricolo VE: Malignant transformation of benign mesenteric cyst. Am / Gastroenterol I994, 89(I I):2085-7.

52. Cohen I, Altaras M, Lew S, et al.: Huge mesenteric mucinous cystadenoma in normal pregnancy. Obstet Gynecol I988, 7 I: 1030-2

53. Czubalski A, Barwijuk A, Radiukiewicz G: Large mesenteric cyst in a patient suspected of ovarian cyst. Ginekol Pol 2004, 75(7):545-7.

54. Felemban A, Tulandi T: Laparoscopic excision of a mesenteric cyst diagnosed preoperatively as an ovarian cyst. J Am Assoc Gynecol Laparosc 2000, 7(3):429-3I.

55. Banerjee R, Gough J: Cystic mucinous tumours of the mesentery and retro-peritoneum: report of three cases. Histopathology 1988, I 2:527-32.

56. McEvoy AW, Cahill CJ, Jameson C: Mucinous cystadenoma of the sigmoid colon: a previously unreported abdominal tumour. Eur J Surg Oncol 1997, 23:88-90.

57. Talwar a, Bell NJ, Nicholas D: Mucinous cystadenoma of colonic mesentery: Report of a case. Dis Colon Rectum 2004, 47:|4|2-|4|4.

58. Linden PA, Ashley SW: Mucinous cystadenocarcinoma of the mesentery. Surgery 2000, I27(6):707-8.

59. Vrettos ME, Kostopoulou E, Papavasileiou C, et al.: A mucinous tumour of the mesocolon with features of borderline malignancy. Surg Endosc 2000, I 4(6):595.

60. Zwaveling S, den Outer AJ, da Costa SA: A mucinous cystadenoma in the mesentery of the right hemicolon. Acta Chir Belg 2008, 108(3):354-5.

61. Payan HM, Gilbert EF: Mesenteric cyst-ovarian implant syndrome. Arch Pathol Lab Med 1987, I I I (3):282-4.

62. Storch MP, Raghavan U: Mucinous cystadenocarcinoma of retroperitoneum. Conn Med 1980, 44:140-I.

63. Lapertosa G: Histogenetic considerations on mucinous cystomas of the ovary based on histochemical and immunohistochemical findings. Pathologica 1989, 8 I:38I-40I.

64. McKenney JK, Soslow RA, Longacre TA: Ovarian mature teratomas with mucinous epithelial neoplasms: morphologic heterogeneity and association with pseudomyxoma peritonei. Am J Surg Pathol 2008, 32(5):645-55.

65. Moid FY, Jones RV: Granulosa cell tumor and mucinous cystadenoma arising in a mature cystic teratoma of the ovary: $A$ unique case report and review of literature. Ann Diagn Pathol 2004, 8(2):96-101.

66. Tang P, Soukkary S, Kahn E: Mature cystic teratoma of the ovary associated with complete colonic wall and mucinous cystadenoma. Ann Clin Lab Sci 2003, 33(4):465-70.

67. Erdogan D, Lamers WH, Offerhaus GJ, et al:: Cystadenomas with ovarian stroma in liver and pancreas: an evolving concept. Dig Surg 2006, 23(3):|86-9|.

68. Lauchlan SC: The secondary Mullerian system. Obstet Gynaecol Surv 1972, 27:133.

69. Lauchlan SC: The secondary müllerian system revisited. Int J Gynecol Pathol 1994, I3(1):73-9.

70. Fujii S, Konishi I, Okamura H, Mori T: Mucinous cystadenocarcinoma of the retroperitoneum: a light and electron microscopic study. Gynecol Oncol 1986, 24:103-12.

7I. Tykkä H, Koivuniemi A: Carcinoma arising in a mesenteric cyst. Am J Surg 1975, I29(6):709-II.

72. Compagno J, Oertel JE: Mucinous cystic neoplasms of the pancreas with overt and latent malignancy (cystadenocarci- 
noma and cystadenoma). A clinicopathologic study of 4l cases. Am J Clin Pathol 1978, 69:573-80.

73. Roth LM, Ehrlich CE: Mucinous cystadenocarcinoma of the retroperitoneum. Obstet Gynecol 1977, 49(4):486-8.

74. Crippa S, Salvia R, Warshaw AL, Domínguez I, et al.: Mucinous cystic neoplasm of the pancreas is not an aggressive entity: lessons from 163 resected patients. Ann Surg 2008, 247(4):57I-9.

75. Wilentz RE, Albores-Saavedra J, Zahurak M, et al:: Pathologic examination accurately predicts prognosis in mucinous cystic neoplasms of the pancreas. Am J Surg Pathol 1999, 23(I I): I320-7.

76. Shimizu $Y$, Yasui K, Yamao K, et al:: Possible oncogenesis of mucinous cystic tumors of the pancreas lacking ovarian-like stroma. Pancreatology 2002, 2(4):4|3-20.

77. Sawai H, Okada $Y$, Funahashi $H$, et al:: Clinicopathological and immunohistochemical analysis of malignant features in mucinous cystic tumors of the pancreas. Hepatogastroenterology 2006, 53(68):286-90.

78. Jeurnink SM, Vleggaar FP, Siersema PD: Overview of the clinica problem: facts and current issues of mucinous cystic neoplasms of the pancreas. Dig Liver Dis 2008, 40(II):837-46.

79. Bassi C, Salvia R, Gumbs AA, et al:: The value of standard serum tumor markers in differentiating mucinous from serous cystic tumors of the pancreas: CEA, Ca 19-9, Ca I25, Ca I53. Langenbecks Arch Surg 2002, 387:28I-5.

80. Murakami Y, Uemura K, Morifuji M, et al:: Mucinous cystic neoplasm of the pancreas with ovarian-type stroma arising in the head of the pancreas: case report and review of the literature. Dig Dis Sci 2006, 5 I (3):629-32.

8I. Beahrs OH, Judd ES Jr, Dockerty MB: Chylous cysts of the abdomen. Surg Clin North Am 1950, 30(4): 108I-96.

82. Ros PR, Olmsted WW, Moser RP Jr, et al.: Mesenteric and omental cysts: Histologic classification with imaging correlation. Radiology 1987, 164:327-332.

83. de Perrot $M$, Bründler $M$, Tötsch $M$, et al:: Mesenteric cysts. Toward less confusion? Dig Surg 2000, I7(4):323-8.

84. Sheth S, Horton KM, Garland MR, et al.: Mesenteric neoplasms: CT appearances of primary and secondary tumors and differential diagnosis. Radiographics 2003, 23(2):457-73.

85. Mennemeyer R, Smith M: Multicystic, peritoneal mesothelioma, a report with electron microscopy of a case mimicking intraabdominal cystic hygroma (lymphangioma). Cancer 1979, 44:692-698.

86. Punpale A, Shrikhande SV, Sumeet G, et al.: Primary neuroendocrine carcinoma presenting as mesenteric cyst. Indian J Gastroenterol 2007, 26(3): 137-8.

87. Shitomi T, Akasaka I, Yamaguchi T, et al.: A case of mesenteric epithelioid leiomyosarcoma showing rapid growth of cystic component. Nippon Shokakibyo Gakkai Zasshi 200I, 98(10): I I79-84

88. McFadden DW, Hiyama D, Moulton JS, et al.: Primary mesenteric leiomyosarcoma masquerading as a pancreatic pseudocyst. Pancreas 1993, 8(5):647-9.

89. Yildirim M, Erkan N, Vardar E: Hydatid cysts with unusual localizations: diagnostic and treatment dilemmas for surgeons. Ann Trop Med Parasitol 2006, I00(2): I37-42.

90. Cöl C, Cöl M, Lafçi H: Unusual localizations of hydatid disease. Acta Med Austriaca 2003, 30(2):6I-4.

91. Mavridis G, Livaditi E, Christopoulos-Geroulanos G: Management of hydatidosis in children. Twenty-one year experience. Eur J Pediatr Surg 2007, 17(6):400-3.

92. Astarcioglu $\mathrm{H}$, Koçdor MA, Topalak $\mathrm{O}$, et al.: Isolated mesosigmoidal hydatid cyst as an unusual cause of colonic obstruction: report of a case. Surg Today 200I, 3I(10):920-2

93. Emir H, Yesildag E, Sahin I, et al.: A case of mesenteric cysts caused by abdominal tuberculosis. Eur J Pediatr Surg 2000, I0(6):402-3

94. Cheung HY, Siu WT, Yau KK, et al.: Acute abdomen: an unusual case of ruptured tuberculous mesenteric abscess. Surg Infect (Larchmt). 2005, 6(2):259-26I.

95. Borisa AD, Bakhshi GD, Tayade MB, et al.: A rare case of tuberculous mesenteric cyst masquerading as chylolymphatic mesenteric cyst. Bombay Hospital Journal 2008, 50(3):
96. Nishino M, Hayakawa K, Minami M, et al.: Primary retroperitoneal neoplasms: CT and MR Imaging findings with anatomic and pathologic diagnostic clues. Radiographics 2003, 23:45-57.

97. Hamrick-Turner JE, Chiechi MV, Abbitt PL, et al.: Neoplastic and inflammatory processes of the peritoneum, omentum, and mesentery: diagnosis with CT. Radiographics 1992, | 2(6): | $05 \mid-68$.

98. Stoupis C, Ros PR, Abbitt PL, et al:: Bubbles in the belly: imaging of cystic mesenteric or omental masses. Radiographics 1994 14(4):729-37

99. Ghossain MA, Braidy CG, Kanso HN, et al:: Extraovarian cystadenomas: ultrasound and MR findings in $\mathbf{7}$ cases. J Comput Assist Tomogr 2005, 29(I):74-9

100. Martínez-Onsurbe P, Ruiz Villaespesa A, Sanz Anquela JM, et al.: Aspiration cytology of 147 adnexal cysts with histologic correlation. Acta Cytol 200I, 45(6):94I-7.

10I. Attasaranya S, Pais S, LeBlanc J, et al.: Endoscopic ultrasoundguided fine needle aspiration and cyst fluid analysis for pancreatic cysts. JOP 2007, 8(5):553-63.

102. Linder JD, Geenen JE, Catalano MF: Cyst fluid analysis obtained by EUS-guided FNA in the evaluation of discrete cystic neoplasms of the pancreas: a prospective single-center experience. Gastrointest Endosc 2006, 64(5):697-702.

103. Ammori BJ, Jenkins BL, Lim PC, et al.: Surgical strategy for cystic diseases of the liver in a western hepatobiliary center. World J Surg 2002, 26:462-469.

104. Kubota E, Katsumi K, lida M, et al.: Biliary cystadenocarcinoma followed up as benign cystadenoma for 10 years. J Gastroenterol 2003, 38:278-282.

105. Horvath KD, Chabot JA: An aggressive resectional approach to cystic neoplasms of the pancreas. Am / Surg 1999, 178:269-274.

106. Walker AR, Putnam TC: Omental, mesenteric, and retroperitoneal cysts: a clinical study of $\mathbf{3 3}$ new cases. Ann Surg 1973, 178(I): 13-9.

107. Hebra A, Brown MF, McGeehin KM, et al:: Mesenteric, omental, and retroperitoneal cysts in children: a clinical study of $\mathbf{2 2}$ cases. South Med J 1993, 86(2): 173-6.

108. Okur H, Küçükaydin M, Ozokutan BH, et al:: Mesenteric, omental, and retroperitoneal cysts in children. Eur J Surg 1997, 163(9):673-7.

109. Trompetas $\mathrm{V}$, Varsamidakis $\mathrm{N}$ : Laparoscopic management of mesenteric cysts. Surg Endosc 2003, I 7( I 2):2036.

I I0. Morrison CP, Wemyss-Holden SA, Maddern GJ: A novel technique for the laparoscopic resection of mesenteric cysts. Surg Endosc 2002, 16(I):219.

III. Shamiyeh A, Rieger R, Schrenk P, et al.: Role of laparoscopic surgery in treatment of mesenteric cysts. Surg Endosc 1999 , 13(9):937-9.

Publish with Biomed Central and every scientist can read your work free of charge

"BioMed Central will be the most significant development for disseminating the results of biomedical research in our lifetime. "

Sir Paul Nurse, Cancer Research UK

Your research papers will be:

- available free of charge to the entire biomedical community

- peer reviewed and published immediately upon acceptance

- cited in PubMed and archived on PubMed Central

- yours - you keep the copyright

Submit your manuscript here:

http://www.biomedcentral.com/info/publishing_adv.asp

BioMedcentral 